\title{
RATIONALISING THE ROLE OF ORANG ASLI IN GO- MANAGEMENT OF THE ROYAL BELUM STATE PARK, MALAYSIA
}

\author{
Kamal SF \\ Department of Anthropology and Sociology, Faculty of Arts and Social Sciences, Universiti Malaya, 50603 Kuala Lumpur, \\ Malaysia; kamal@um.edu.my
}

Submitted January 2020; accepted May 2020

\begin{abstract}
This paper reports on the possibility for collaborative management of the Royal Belum State Park between the Perak State Park Corporation and the indigenous inhabitants. International standards in managing conservation areas recognise a complex web of interests that includes conservation, business, and indigenous rights. In line with this, the Malaysian Biodiversity Policy includes requirements for public participation and the recognition of cultural rights of indigenous communities in protected areas. Intangible values of parks were used to show that conservation efforts and indigenous rights converge and share commonalities in values. This paper argues that inclusion of Orang Asli as co-managers requires genuine partnership founded on consultation as well as recognition of their customary rights and knowledge of the landscape. Extending from these principles, the recommendations include developing infrastructure capacity, creating economic opportunities, addressing human-animal conflict, developing a fair and representational benefit sharing mechanism and allowing traditional use of natural resources which includes integrating traditional knowledge with natural resources management strategies.
\end{abstract}

Keywords: Intangible values, protected areas, co-managing protected areas, indigenous inhabitants, customary land

\section{INTRODUCTION}

The Malaysian Biodiversity Policy incorporates the Aichi Biodiversity Targets and IUCN Protected Area Categories by including the requirements for public participation and the recognition of cultural rights of communities in protected areas. However, many Orang Asli communities do not feel included in park conservation efforts. Traditionally, park management in Peninsular Malaysia has a top-down approach and do not readily recognise claims by the indigenous inhabitants as customary landowners. This paper reports a case study of the Royal Belum State Park (RBSP), looking at how the park management authority can work towards incorporating indigenous peoples in management of protected area by linking intangible values of parks to the Orang Asli way of life and value system.

Orang Asli is a term used in reference to the indigenous minorities of Peninsular Malaysia. It is a legal term enshrined in the Aboriginal Peoples Act 134 of 1954. Three subgroups make up the indigenous peoples in Peninsular Malaysia, namely, Senoi, Negrito and Proto-Malay. As of 2018, the Orang Asli population stood at approximately 178,197 (JAKOA 2018). The most populous subgroup is the Senoi, followed by Proto-Malay, and lastly Negrito.
This work applied the Harmon's (2004) proposition that intangible values of parks are in line with indigenous values. The common principles and interests shared by modern values in conservation and the way of life of indigenous peoples lend support to a framework that enables the participation of indigenous peoples as comanagers of protected area. Such collaboration can be mutually beneficial, allowing greater autonomy and access for the communities, while improving government surveillance to monitor activities within parks (Kamal \& Lim 2019).

The Perak State Park Corporation (PSPC) Management Plan for the Royal Belum State Park (RBSP) which was published in 2017 incorporates strategies for the inclusion of Orang Asli in conservation and ecotourism initiatives. However, in practice, management of the RBSP is still highly state-centric and top-down in approach, and there are gaps in indigenous participation in park management. While a number of Orang Asli have been hired in support positions, this is yet to be seen in management and decisionmaking roles, and there are opportunities to further increase their participation in park management. So far, there have been plans to expand Orang Asli participation in ecotourism 
initiatives. To achieve this objective, the PSPC has reached out to NGOs to develop the capacity of the Orang Asli. Yet, after more than a decade since the creation of RBSP, these efforts remain underdeveloped. This paper argues for the incorporation of Orang Asli participation into the management structure of the RBSP. It also offers recommendations on reforms to facilitate indigenous participation in park management based on Harmon's (2004) proposition of the intangible values of parks being in line with indigenous values.

\section{MATERIALS AND METHODS}

Data were collected in 2012-2019 over an extended period using what Jeffrey and Troman (2004) termed as selective intermittent mode of ethnography fieldwork. The selective intermittent mode is described as being longer in time, being anywhere from three months to two years, and is more flexible with the researcher slowly zooming in to focus on the relevant aspects of research combining specific contexts, respondents' interpretations and researcher-respondent discussion and conversation (Jeffrey \& Troman 2004). Ethnography is a qualitative research methodology. Several methods in data collection were employed, including reviewing policy, participant observation and informal interviews. The interviews were conducted with different stakeholders, including village elders living in Kampung (Kg.) Sungai (Sg.) Kejar, Kg. Jerai, $\mathrm{Kg}$. Bongor Hilir and Kg. Tahein, PSPC, and an independent consultant. The ethnography employed was inductive, contextual, flexible and multi-sited. This research acknowledged that the PSPC had taken efforts to adapt different approaches to develop the park, with the recognition that the welfare and involvement of indigenous inhabitants was an important aspect of park management responsibility. Insight gained from the RBSP Management Plan (20182027) helped shape the discussion in this paper.

\section{RESULTS AND DISCUSSION}

The intangible values discussed by Harmon (2004) include recreational values, therapeutic values, spiritual values, cultural values, identity values, existence values, artistic values, aesthetic values, educational values, scientific values, and peace values. The premise of Harmon's (2004) argument is that parks are conserved not just for their tangible values, but also because the act of conservation reflects an inherent value deeply rooted in our modern condition.

The inherent values in parks transcend monetary or material values, and are expressions of modernity. Harmon (2004) offers insight into how these intangible values are compatible with indigenous perspectives on the value of protected areas. These values and the protective impulse are embodied in their way of life and belief system. One value that plays a central role in the Orang Asli way of life is that they do not see themselves as separate from nature. Rather, they are part of nature and they believe in the agency of nature to retaliate in response to human misbehaviour (Thambiah et al. 2018).

For indigenous communities such as the Orang Asli in Peninsular Malaysia, their traditional territory are ecological space, that they have occupied over generations, and they have acquired specific knowledge to survive in these spaces. They have rich knowledge of the forest and feel a deep spiritual bond to these spaces. Their relationship to their customary land is rooted in their belief system, empirical knowledge and cultural narratives. The intangible values of parks and the Orang Asli's relationship to their landscape would cover almost all the values in Harmon's (2004) taxonomy, though the more relevant ones include spiritual values, cultural values and identity values. However, one can easily appreciate the therapeutic values of the forest to the Orang Asli. The wealth of knowledge the Orang Asli have of the forest is useful to researchers and holds significant scientific values (Lim 2013).

\section{Belum-Temengor rainforest complex}

Located in the north of Peninsular Malaysia in the state of Perak, the RBSP is part of the Belum-Temengor rainforest complex covering approximately 300,000 ha. It is surrounded by the Grik Forest Reserve (FR), the Belum FR (sometimes referred as Aman Damai FR), and the Temengor FR. While the RBSP is a totally protected area spanning 117,500 ha, the other forest reserves around it are designated as commercially productive forest reserves. Separated from the Temengor FR by the eastwest highway, the RBSP neighbours the Hala-Bala National Park in Thailand. 
While expressing support for the creation of the RBSP, conservationists have expressed concerns about the commercial activities in the surrounding areas, arguing that protection for the RBSP should include the Temengor FR and extend to other national and state parks that exist along the central forest spine (Schwabe et al. 2015). The concerns included the overall integrity of the forest and protection of wildlife, particularly far-ranging large mammals such as the Malayan tiger. Schwabe et al. (2015) raised three unresolved issues in the management of BelumTemengor; a more comprehensive management; a plan to cover the larger forest network to address poaching; and the implementation of sustainable ecotourism.

Scholars also acknowledge the vulnerability of indigenous communities, and the possible negative impact felt by these communities resulting from interventions including ecotourism, commercial agriculture, logging, as well as threats from conservation efforts and the creation of parks itself (Kamal et al. 2013, Schwabe et al. 2015). As park management often focuses on conservation and the protection of flora and fauna, the orang Asli often find their livelihood strategies under threat. Some of their activities are deemed as poaching and they risked being arrested.

\section{The Orang Asli in Belum-Temengor rainforest complex}

The indigenous peoples within the BelumTemengor are predominantly made up of Jahai communities with a significant presence of Temiar in Temengor. According to the 2011 figures from the Department of Orang Asli Development and Welfare (JAKOA), the Orang Asli population in Belum-Temengor is approximately 2346 individuals from 457 families (Kamal et al. 2013). RPS (Rancangan Pengumpulan Semula or Regroupment Scheme) Air Banun serves as the main settlement. Other large settlements include $\mathrm{Kg}$. Sg. Tiang in RBSP and Sg. Chiong in the lower part of the Temengor. In addition, there are estimates of 15 smaller settlements spread out across the landscape. The existence of these hamlets is fluid and is influenced by different factors, such as subsistence needs and internal discord within the larger community.

There are approximately 800 Orang Asli (i.e. Jahai) individuals in the RBSP. They occupy several areas in the RBSP with $\mathrm{Kg}$. Sg. Tiang and $\mathrm{Kg}$. Sg. Kejar being the main settlements. Located closer to Kg. Sg. Tiang are Kg. Aman Damai and Kg. Serai Wangi. The settlements near to Kg. Sg. Kejar include Kg. Jerai, Kg. Tahein, and Kg. Bongor Hilir. The existence of the smaller hamlets is fluid and several may have moved to newer sites, thus abandoning previous settlements.

Descriptions of the Jahai relationship to the forest are well captured by scholars (Schebesta 1973, Gomes 2007). Their way of life is one that embodies the forest in both their livelihood practices and their belief system. Thus, fear of alienation and its consequence to the community is a significant concern (Gomes 2007).

\section{The resettlement of the Orang Asli}

In the mid 1970's, the government made the decision to resettle the Orang Asli from the Belum-Temengor under the regroupment scheme (RPS). They were resettled in RPS Air Banun. The decision was made partly in response to the Emergency situation, but also partly because of the construction of a hydroelectric dam, which inundated the Belum-Temengor valley in 1978 (Schwabe et al. 2015). Officially, resettlement of the Orang Asli communities was to develop the communities by addressing hardcore poverty, their inclusion in the mainstream way of life without moving them out of their customary areas, and addressing security concerns (Nicholas 2000). However, a common complaint from the Orang Asli in RPS Air Banun was the failure to provide any sustained economic livelihood projects. In the beginning of the RPS, there were other fundamental problems, one of which was that it did not consider local sentiments on their relationship to the forest and to land. After about a decade of living in difficulty at the resettlement site, many of the Orang Asli migrated out of the RPS and returned to their customary land along river tributaries.

There have been different ways in which claims to Orang Asli customary land have been described, including how the area is defined, who has access, and how ownership is transmitted (Edo 1998, Gomes 2007). Jahai elders describe the Belum-Temengor as having several customary land claims by different Jahai communities. In the past, access to customary 
land were strictly monitored by Orang Asli communities based on kin relations or if one had sought permission to enter the area.

Recently, the question on territory and boundary had resurfaced among the Orang Asli communities as they worked together to map their landscape. Although united over the perceived encroachment, the community remained divided on how to look at boundaries and territorial integrity. Some groups continued to hold on to the customary claims based on group affiliations and their river areas. Others perceived a need to consolidate to form a cohesive response against non-Orang Asli whom they viewed to be encroaching into their customary territory.

\section{Issues and challenges in the RBSP}

Infrastructure facilities varied among the settlements in the RBSP, with $\mathrm{Kg}$. Sg. Tiang being the most equipped. Residents at Kg. Sg. Tiang had access to pre-school, primary school, electricity (although still limited and solar may not be reliable), government-built houses, piped water, public flush toilets, a community hall, a prayer hall and a sundry shop. There was ongoing infrastructure development in $\mathrm{Kg}$. Sg. Kejar and $\mathrm{Kg}$. Bongor Hilir. The other villages continued to access water from nearby streams and lived in bamboo houses. Depending on their level of income, they might rely on oil lamps or generators for light. Most families continued to cook using firewood and for most households, there were no flush toilets.

Access to learning opportunities for children in the RBSP varied. Most of the children attended pre-school at Kg. Sg. Kejar, Kg. Bongor Hilir or Kg. Sg. Tiang. In 2008, EMKAY Foundation initiated a CSR effort where it established the i-Play Toy Library programme in the BelumTemengor. However, response to the Toy Library was divided among the Orang Asli. Older members of the community, particularly from Kg. Sg. Kejar viewed the initiative with mistrust, while others embraced the initiative. Current teachers for the Toy Library included women from Kg. Sg. Tiang. It may be of significance to note that the EMKAY group has considerable interests in the Belum-Temengor. They have two foundations that base their work in the area: EMKAY Foundation that looks at philanthropic initiatives, and Pulau Banding Foundation that promotes research and ecotourism through sustainable development. They also own the Belum Rainforest Resort.

Primary schooling is available in Kg. Sg. Tiang with a pre-schooling facility now available in $\mathrm{Kg}$. Bongor Hilir. More recently, a Dewan Baca or reading hall had been established at $\mathrm{Kg}$. Tahein. The teacher was a Semai who formerly taught at KEDAP (Kelas Dewasa Asli Pribumi or Indigenous Adult Literacy Class). Several students had progressed into secondary level schooling, but in order to access those schools, they had to travel to Gerik town which is located approximately 40 $\mathrm{km}$ away. Many children did not attend school regularly due to internal conflict within Orang Asli communities in the RBSP and irregular access to transportation. Village elders in $\mathrm{Kg}$. Tahein, Kg. Bongor Hilir and Kg. Sg. Kejar often requested for a permanent teacher to be based in their villages to teach literacy for children and adults. Issues faced by Orang Asli living within the RBSP could be grouped into six themes. These were (1) human-wildlife conflict, (2) not being acknowledged as customary landowners, (3) fear of encroachment, (4) outsiders as the main beneficiary from ecotourism in RBSP, (5) lack of formal engagement with government agencies and (6) threats from enforcement agencies against livelihood practices based on commercial trade of forest products (NCIA 2012).

One common worry among the Orang Asli was the encroachment of elephants into villages, which damaged crops and posed a risk to villagers' safety and lives. In several communities in the RBSP, the Orang Asli complained about elephants entering their orchards. In 2015, Kg. Aman Damai reported the encroachment of elephants in their village. They complained of inaction by the authorities to address this threat.

Another longstanding issue was the recognition of customary land rights of the Orang Asli. The Orang Asli wanted authorities to recognise these rights and acknowledge them as custodians of the land. Beyond being accorded recognition as customary landowners, the communities expressed disappointment that outsiders including tourists and tour operators often did not ask them for permission before entering their territory. Consequently, they expressed anxiety over encroachment in to the RBSP.

The Orang Asli communities in the RBSP also expressed that they had low participation in ecotourism initiatives within the RBSP. The sentiment was that the beneficiaries of 
ecotourism at RBSP were mainly outsiders. Recently, the RBSP had started discussions with the Orang Asli and had initiated programmes aiming to empower the communities for greater involvement in tourism. These initiatives were still in their early stages and the effectiveness remained to be seen.

Another common complaint from the Orang Asli was that government agencies did not engage with their communities on issues related to the forest in RBSP. The Orang Asli had livelihood practices and beliefs, which were deeply connected to their customary land, and they had expressed that they wished to be consulted on matters that relate to forest conservation and natural resource management. Recent focus on anti-poaching activities had also caused concern among the indigenous communities in the RBSP, who worry that livelihood practices might be deemed illegal. They also expressed indignation at having their activities monitored and regulated by others as they felt they were indigenous to the RBSP.

\section{Convergence of values}

The Orang Asli identified closely with the forest. Jahai elders narrated stories of origins in which, they identified their ancestors as being integral to populating the land with flora and fauna. The encroachments they experienced give rise to anxiety. Thus, when meeting with the men at $\mathrm{Kg}$. Bongor Hilir or Kg. Sg. Kejar, they frequently talked about encroachment, telling and re-telling stories of their grievances from their encounters with outsiders, and always reaffirming custodial claims to the land.

Orang Asli ethos is compatible with conservation values (Lye 2002). In analysing the problem between the Batek community and conservation in Taman Negara, Lye (2002) used the analytical categories of nostalgia and modernity in conservation to argue that there was compatibility between conservation planning and Batek concerns. The author observed that the problem with incorporating Batek knowledge in conservation lay with the pre-existing attitudes that conservation planners have towards indigenous knowledge.

Harmon (2004) suggested that seeking recognition as a World Heritage Site might be the incentive needed to motivate parks to recognise indigenous peoples as stakeholders. However, several steps are needed to ensure genuine participation. For RBSP, these include having effective consultative processes, acknowledging Orang Asli customary claims, and recognising indigenous knowledge as effective mechanisms in conservation practices.

One way forward in ensuring an effective consultation process, is that the PSPC can incorporate the principle of Free, Prior and Informed Consent (FPIC) in their work processes. This is not an unheard-of practice for businesses, which apply sustainable development principles when working in areas with indigenous peoples, or for financial institutions which have guidelines requiring adherence to FPIC (ZafraCalvo et al. 2017, Reo et al. 2017). FPIC aims at achieving more effective bottom-up participation by establishing an obligation to consult-or obtain the consent of-indigenous peoples before large development projects and legal reforms affecting them can proceed (Fontana \& Grugel 2016).

In order to encourage Orang Asli participation in park initiatives, the management of the RBSP must formally recognise the community's claims to customary land. It is difficult for the Orang Asli to engage in programmes organised by the RBSP if there is no recognition of their distinct status as indigenous peoples, as well as their knowledge of the landscape. Orang Asli want recognition as a culturally distinct people with deep roots to the ecological niches they live within, and they want security of tenure in these landscapes (Nicholas 2002). Orang Asli seek a guaranteed decent standard of living. Finally, the Orang Asli call for the recognition that they possess indigenous knowledge, which can be adapted to the management of natural resources. However, for this to happen, fundamental changes are needed in the way the RBSP operates. Reforms in policy are required in order to develop institutional capacity and, community capacity to engage the Orang Asli constructively and progressively as co-managers in park management. Various organisations have acknowledged the presence of Orang Asli and the need for integrating them within the activity of the park (NCIA 2012). However, there was no official policy or practice aimed at recognising indigenous rights and needs in the RBSP. Earlier initiatives to engage with villagers were often conducted on informal bases. Nevertheless, there appeared to be a softening of stance towards the 
presence of Orang Asli and their subsistence activities within the park. The park recognised that the communities were dependent on the natural resource for their livelihood, and now offered leeway in enforcing regulations. While the rangers were not happy that the Orang Asli were clearing land for cultivation, felling trees in search for honey or hunting in the forest, they now recognised that these were acceptable for the purpose of meeting the subsistence needs of these communities.

More recent policy by the RBSP in their Management Plan for 2018-2027 recognised indigenous customary rights, and acknowledged that grievances from among the Orang Asli need to be addressed in determining the future direction of the park. The management plan sounds promising in that it clearly states the Orang Asli have traditional knowledge applicable to conservation, that they are seen as allies to the park and that it recognises Orang Asli as equal partners in park management (PSPC 2017). The challenge moving forward is seeing the management plan translate into an effective and equally benefitting partnership.

\section{RECOMMENDATIONS}

The challenges faced by the PSPC in managing the RBSP echoes the work of scholars who write about collaborative management in Sabah. Vaz and Agama (2013), Tongkul et al. (2013), and Voo et al. (2016) offer case studies in Bundu Tuhan Native Reserves, Banggi island communities and the protection of sacred sites, and the development of Community Use Zones (CUZs) for the Crocker Range Park Management Plan respectively. Their works suggest that the conversation between government agencies and indigenous communities have started, and in several instances, there are now legal structures to support collaboration. Similar efforts at building bridges between Orang Asli and the management of the RBSP can take place here.

Recognising the complex challenges in the RBSP is the first step forward in moving towards reconciling the perceived differences between indigenous communities and the PSPC. However, both stakeholders share a common goal in conservation. The recommendations discussed below offer practical solutions towards incorporating the Orang Asli in the efforts to manage the RBSP.
First, the management of the RBSP needs to officially acknowledge claims made by the Jahai communities living within the RBSP. This means recognising that the RBSP is the customary land to the Jahai communities living in the area. In practice, the PSPC can facilitate registration of the Jahai as customary landowners. This can be arranged through JAKOA or made official by the state government.

Second, the Jahai living within the RBSP must benefit from development efforts within the area. A needs analysis and a strategic plan should be discussed among the stakeholders. Engaging the indigenous communities within the RBSP in consultation is a useful mechanism for capturing the diverse and disparate segments of the population. Such a mechanism can be far more representational when put in practice.

Third, community elders have commented that the RBSP should pay the Orang Asli a weekly stipend, not just to cover their subsistence needs but also to compensate them as landowners. Payment should not be seen as charity or welfare. The stipend can be seen as a form of rent payment, and is collected from dividend or interests earned from the park. Village elders argue for a weekly payment for practicality purposes, as it fits into how the Jahai manage their resources.

Fourth, there should be more focus on infrastructure development. In Kg. Sg. Kejar, Kg. Bongor Hilir and Kg. Tahein, there are gaps in infrastructure facilities between the state park owned chalets and the Orang Asli villages. The villages do not have piped water supplying all houses. Water is either funnelled by pipe from nearby streams, or villagers (mostly women) have to walk a distant to fetch water to their homes. In the case of $\mathrm{Kg}$. Tahein, the villagers have to take their boats across to a small stream where they collect clean water.

Fifth, there is a need to look at providing electricity. There are several abandoned microhydro projects in the area. For example, an almost complete micro-hydro set up lay abandoned just outside of $\mathrm{Kg}$. Sg. Kejar village. Perhaps the RBSP can find funding and technical partners, such as Tonibong (a Sabah-based NGO which focuses on delivering micro-hydroelectricity to interior communities), TNB (the Malaysian electricity company) or engineering faculties in local public universities to utilise the existing infrastructure. 
Sixth, there is a lack of functional indoor toilets or flush toilets. Currently, some villages in the upper reaches of the RBSP have flush toilets, but these are not always in use. Villagers in $\mathrm{Kg}$. Jerai build their own makeshift covered toilet, but waste is channeled into a stream below the village. There are no flush toilets in Kg. Tahein. There are toilets in $\mathrm{Kg}$. Kejar but they are dilapidated. $\mathrm{Kg}$. Bongor Hilir has new houses built by the government, which have indoor toilets.

Seventh, there is limited mobility for the Orang Asli as there are not enough boats, and they often lack money to purchase petrol. Each village should have a number of boats with regular engine service and access to a petrol quota for common use (e.g. for transportation to school, to the main jetty or for emergencies). The youth among the communities could be trained as mechanics to meet local demand.

Eighth, there is a need for creating greater economic opportunities and representation of the Orang Asli. RBSP can offer jobs to the community to counter poaching activities. For a start, the Orang Asli can be trained as guides and rangers in the RBSP. This is a practical win-win solution that provides an income source to the Orang Asli and reduces dependency on poaching, while at the same time allowing the park to exercise surveillance over a greater area of the landscape. Taking into consideration the size of the park and challenges in enforcement, partnerships can be a cost-effective and quicker way to develop competent capacity. Such employment can be institutionalised within the PSPC. Over time, the Orang Asli can work as boatmen or tour guides, as personnel running daily operations, as rangers, managers and support staff of the RBSP. The goal should be towards having Orang Asli represented in the management board of the RBSP. The RBSP management is currently undertaking these endeavours. However, a challenge to providing employment for the Orang Asli, particularly in the RBSP management, is providing employment security with secure career pathways. Thus, employment opportunity within the RBSP organisation should include health insurance, pension, upskilling and offering opportunity for career advancement.

Ninth, the PSPC needs to address humanwildlife conflict. The state park management should invite research groups such as the Management and Ecology of Malaysian Elephants, Malaysian Nature Society, World Wide Fund for
Nature, and partner with Department of Wildlife and National Parks Peninsular Malaysia to address marauding elephants in the landscape. For example, they can develop a protocol on how to engage elephants when they encroach into villages and fields. At the same time, the Orang Asli can be trained to be field technicians to help scientists monitor species population and change.

Tenth, the park authorities should allow Orang Asli communities to continue with their traditional use of natural resources. Cultural practice and values can be documented and used to demonstrate respect and recognition of Orang Asli as customary landowners. They have sacred sites within the landscape, and indigenous knowledge, which can be incorporated as part of natural resource management strategies.

\section{CONCLUSIONS}

This study explored the possibility of recognising a convergence of interests between conservation values and indigenous cultural and identity values in accepting the Orang Asli as co-managers in the RBSP. Intangible values can be applied to Orang Asli values with conservation values in the effort to improve the management of RBSP. To the Orang Asli, the forest is important as an ecological environment in which they survive. Their spirituality, culture and identity are interwoven with the landscape of the RBSP. On the other hand, the PSPC's stated vision and mission aim for the protection of the landscape for biodiversity conservation. The special role of the Orang Asli as indigenous to the landscape and have an important role to play in conservation is already acknowledged in the RBSP Management Plan 2018-2027.

The involvement of indigenous peoples is deemed essential for the long-term sustainability of protected areas and, therefore, their involvement in park planning, decision-making and local empowerment are issues that must be addressed. What this entails is that agencies involved in protected area management must work from the premise that these areas in which they work are customary territory of the Orang Asli.

Discussion on reforms should help illuminate some of the key institutional barriers that need to be overcome in order to incorporate Orang Asli as co-managers in the RBSP. As the premise 
for co-management lies with the ability of the park to incorporate these changes as outlined in their new RBSP Management Plan 2018-2027, the challenge now rests with the capacity of the PSPC as a management body.

\section{ACKNOWLEDGEMENTS}

The case study was funded by a research grant (RPO42B-17HNE) from Universiti Malaya and supported by the Center for Malaysian Indigenous Studies, Universiti Malaya.

\section{REFERENCES}

EDO J. 1998. Claiming our ancestors' land: an ethnohistorical study of Seng-oi land rights in Perak, Malaysia. PhD thesis, Australian National University, Canberra.

Fontana LB \& Grugel J. 2016. The politics of indigenous participation through "free prior informed consent": reflections from the Bolivian case. World Development 77: 249-261. http://dx.doi.org/doi:10.1016/j. worlddev.2015.08.023.

Gomes GA. 2007. Modernity and Malaysia: Settling the Menraq Forest Nomads. Routledge, London.

HaRmon D. 2004. Intangible values of protected areas: What are they? Why do they matter? The George Wright Forum 21: 9-22.

JakoA (Department of Orang Asli Development and Welfare). 2018. Statistik penduduk OA mengikut negeri dan jantina (sehingga November 2018). Accessed 11 May 2020 from https://www.data. gov.my/data/dataset/62cda616-a118-4f69-ad58382cec9491ee/resource/e3f93bb1-b33a-44ab-966c68ac15aae9e8/download/jakoastatistik-pendudukmasyarakat-orang-asli-mengikut-negeri-dan-jantina. xlsx.

Jefretey B \& Troman G. 2004. Time for ethnography. British Educational Research Journal 30: 535-548.

Kamal SF, Tracey I, Edo J, Rosilawati Z, Siti NA \& Wan Suzita WI. 2013. Sociological studies and dependence of the Orang Asli population on Sg. Enam Basin. Pp 73-93 in Abdul Latiff $\mathrm{M}$ et al. (eds) Proceeding of The $2^{\text {nd }}$ Temengor Scientific Expedition 2012. Pulau Banding Foundation, Petaling Jaya.

KAMAL SF \& LiM VC. 2019. Forest reserve as an inclusive or exclusive space? Engaging Orang Asli as stakeholder in protected area management. Journal of Tropical Forest Science 31: 278-285.

Lim BL. 2013. Reminiscences: My Associations with Orang Asli. Occasional Paper Series. Universiti Malaya, Kuala Lumpur.

LyE TP. 2002. Forest People, Conservation, Boundaries, and the Problem of 'Modernity' in Malaysia. Pp 160-184 in Benjamin G \& Chou C (eds) Tribal Communities in the Malay World: Historical, Cultural and Social Perspectives. ISEAS, Singapore.

NCIA (Northern Corridor Implementation Authority) 2012. Appendix 3: FGDs with Orang Asli. Pp 1-26 in Integrated Master Plan for Belum Temengor Tropical Rainforest Final Report. Volume III. NCIA, Simpang Ampat.

Nicholas C. 2000. The Orang Asli and the Contest for Resources: Indigenous Politics, Development and Identity in Peninsular Malaysia. IWGIA Document No. 95. IWGIA, Copenhagen.

NiCHOLAS C. 2002. Participation and recognition of Orang Asli as stakeholders in protected areas management. Paper presented at the National Workshop on Protected Areas Management: Direction for the Future. 14-16 January 2002, Kuala Lumpur.

PSPC (Perak State Park Corporation). 2017. Royal Belum State Park Management Plan 2018-2027. PSPC, Gerik.

Reo NJ, Whyte KP, McGregor D, Smith MA \& Jenkins JF. 2017. Factors that support indigenous involvement in multi-actor environmental stewardship. AlterNative: An International Journal of Indigenous Peoples 13: 58-68. https://doi.org/10.1177/1177180117701028.

Schwabe KA, Carson RT, De Shazo jr, Matthew D. Potts A, Reese N \& Vincent JR. 2015. Creation of Malaysia's Royal Belum State Park: a case study of conservation in a developing country. The Journal of Environment and Development 24: 54-81. https://doi. org/10.1177/1070496514551173.

Schebesta P. 1973. Among the Forest Dwarfs of Malaya. Oxford University Press, Kuala Lumpur:

Thambiah S, Tijah YC \& Rosalind LYL. 2018. Reclaiming the eclipsed female in the sacred: Semai women's religious knowledge and its connection to their rights to the land, in Malaysia. Bijdragen tot de Taal-, Land-en Volkenkunde 174. 264-290. https:///doi. org/10.1163/22134379-17402002.

Tongkul F, Lasimbang C, Lasimbang A \& Chin P Jr. 2013. Traditional knowledge and SFM: experience from Malaysia. Unasylva 240 64: 41-49.

Vaz J \& Agama AL. 2013. Seeking synergy between community and state-based governance for biodiversity conservation: the role of indigenous and community-conserved areas in Sabah, Malaysian Borneo. Asia Pacific Viewpoint 54: 141-157. https:// doi.org/10.1111/apv.12015.

Voo P, Abrar JM \& Inoue M. 2016. Community Use Zone (CUZ) model and its outcome in Malaysia case study from Crocker Range Park, Sabah. Journal of Management and Sustainability 63: 25-33. doi: 10.5539/jms.v6n3p25.

Zafra-Calvo N, Pascua, U, Brockington D et al. 2017. Towards an indicator system to assess equitable management in protected areas. Biological Conservation 211: 134141. https://doi.org/10.1016/j.biocon.2017.05.014. 